\title{
Zero-Waste: A New Sustainability Paradigm for Addressing the Global Waste Problem
}

\author{
Atiq Zaman
}

\section{Contents}

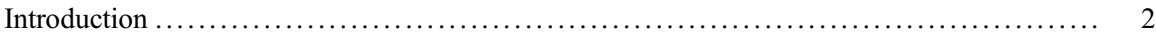

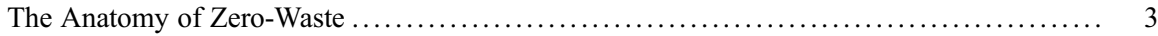

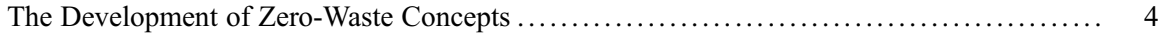

The Enigma of Consumerism, Environmental Degradation, and Zero-Waste $\ldots \ldots \ldots \ldots \ldots \ldots$. 6

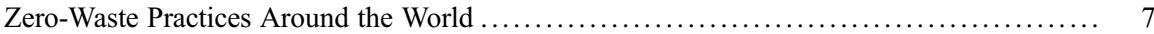

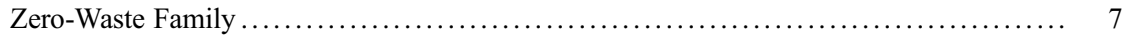

Kamikatsu, Japan: A Zero-Waste Community ................................... 9

Kamikatsu Community ................................................... 9

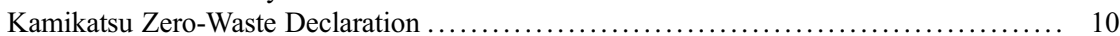

Zero-Waste Practices at the Kamikatsu Community ............................. 10

Zero-Waste Business ..................................................... 12

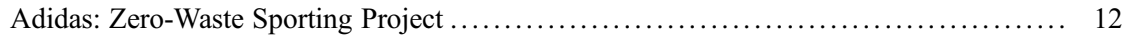

The Zero-Waste Stores to Phase -Out Unnecessary Packaging ...................... 13

Zero-Waste City: The Case Study of San Francisco, USA ........................... 14

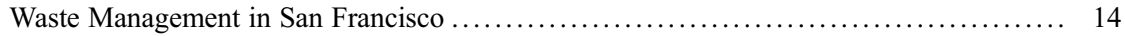

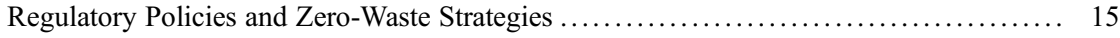

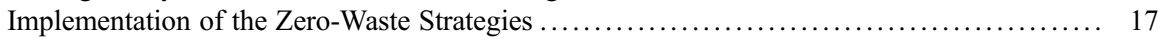

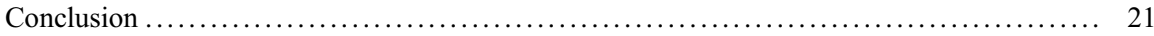

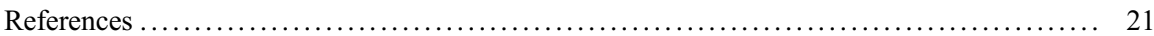

\section{Abstract}

There is a growing interest in addressing global waste problems by applying innovative ideas and philosophies such as zero-waste and circular economy. As a new sustainability paradigm, zero-waste challenges the common assumption of waste as a valueless and unavoidable by-product created at the end of the product's life phase. Instead, it acknowledges that waste is a "misallocated resource" or "resource in transition"; produced during the intermediate phases

\footnotetext{
A. Zaman $(\bowtie)$

Curtin University Sustainability Policy Institute, School of Design and the Built Environment, Curtin University, Perth, WA, Australia e-mail: atiq.zaman@curtin.edu.au
} 
of production and consumption activities. Waste should be recirculated to production and consumption processes. Therefore, zero waste means no "waste" would be wasted under the circular economy system. This chapter presents various examples of zero-waste practices derived from family, community, business, and city levels. In addition, zero-waste implementation strategies and actions are also discussed in the chapter. Despite its potential, the visionary zero-waste goals cannot be achieved without responsible global stewardship and active citizens' role.

\section{Keywords}

Zero-waste $\cdot$ Consumerism $\cdot$ Sustainable design $\cdot$ Waste diversion $\cdot$ Value hill $\cdot$ Circular economy

\section{Introduction}

With a growing interest and raising awareness of sustainability, waste has become one of the focal points of sustainable urban development. Yet, it is still one of the least priority areas for allocating budget and necessary infrastructure in many countries around the world. Millions of people's livelihoods in various parts of the world depend on collecting and recycling waste. According to the World Bank's report, around USD 205 billion was spent on waste management worldwide in 2010, and it is predicted that the cost will increase to USD 375 billion by 2025 (World Bank 2012).

Despite technological advancement and engineering solutions, one-third of the global waste is managed in environmentally unsafe manners such as littering, open dumping, open burning and unsanitary landfill, etc. (Kaza et al. 2018). Globally, around $85 \%$ of the collected waste is sent to landfills, including uncontrolled landfills and open dumping, and only $15 \%$ of the collected waste is recycled (Zaman 2016). To date, the landfill is the leading waste management option because of the low management cost (Hoornweg and Bhada-Tata 2012). Although the actual environmental cost of landfill is significantly higher, unfortunately, the traditional market-driven economic system often ignores the environmental costs of the pollution caused by landfills (Eriksson et al. 2005).

Plastic waste pollution is a major environmental concern since $79 \%$ of all plastics we generate are ended up in some form in the environment through land or water. These plastics will continue to pollute the environment for hundreds of years as plastics' decomposition rate is generally prolonged. It was estimated that the emissions from plastics in 2015 were equivalent to nearly 1.8 billion metric tons of carbon dioxide $\left(\mathrm{CO}_{2}\right)$, and it will reach $17 \%$ of the global carbon budget by 2050 (Zheng and Suh 2019). The recent discovery of the Great Pacific Garbage Patch illustrates the level of long-term pollution and damage occurring in our marine environment. 
Urbanization and overconsuming lifestyle trends are the key challenges related to sustainable waste management (Zaman and Ahsan 2019). Cities expand horizontally and vertically to accommodate many people every year (Ahsan and Zaman 2014). According to the UN report, the global urban population has increased by a factor of five, from 0.7 billion in 1950 to 3.9 billion in 2014, and it is expected to increase by another 60 percent by 2050 (UN-DESA 2014). At the same time, global consumption of natural resources could almost triple to 140 billion tons a year, as predicted by the United Nations (SMH 2011). A study indicates that, even with a more aggressive sustainability growth scenario and a drastic waste reduction in intensity by $30 \%$, the global "waste peak" will occur after 2075 (Hoornweg et al. 2014). This indicates that even with our best intention and efforts, the waste generation will continue to increase until the end of this century.

Therefore, a paradigm shift is urgently needed to address the ever-growing global challenges. China was once seen as a global hub for receiving and treating a significant amount of waste from different parts of the world. Since the China Waste Ban (24 different categories) in 2018, countries worldwide are experiencing significant challenges to manage waste locally. Innovative ideas and solutions are urgently needed to overcome the current waste crisis. This book chapter presents a critical analysis of the emerging concept of "zero-waste" as a new sustainability paradigm for addressing the global waste management system's core problems.

\section{The Anatomy of Zero-Waste}

The term "waste" is commonly referred to as the valueless by-product that emerges at the end of life phase, and the substance needs to be disposed of or incinerated for proper management. The concept of zero-waste directly challenges the common assumption of waste as a valueless and unavoidable by-product created at the end of the product's life phase. Zero-waste acknowledges that waste is a "misallocated resource" or "resource in transition" which is produced during the intermediate phases of production and consumption activities, and thus, it should be recirculated to production and consumption processes through reuse, recycling, reassemble, resell, redesign, or reprocess (Zaman and Ahsan 2019). Zero-waste does not see "waste" as a substance that must be disposed of or incinerated but considers waste as a resource that should be used repeatedly (Glavic and Lukman 2007).

The Zero Waste International Alliance (2018) defines zero-waste as "the conservation of all resources through responsible production, consumption, reuse, and recovery of products, packaging, and materials without burning and with no discharges to land, water, or air that threaten the environment or human health." This implies that zero-waste as a concept is a target for transforming waste management systems towards a "circular economy," where extraction, production, and consumption become increasingly waste-free. Zero-waste doesn't mean that we would not create any "waste" in the transition of resource extraction, production, and consumption. Rather, it means no "waste" would be wasted under the circular economy system. 

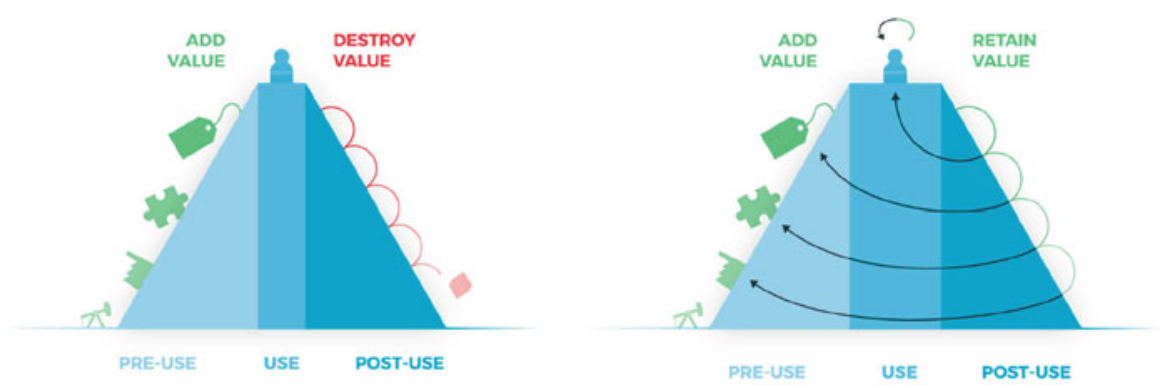

Fig. 1 The value hill as a business strategy tool. (Credit: Achterberg et al. 2016)

Zero-waste is a vision, a target, and an aspiration to progress towards sustainable management of waste. The underpinning principle of zero-waste is retaining the value of products instead of depleting the value of the resources. The value retaining strategy proposed by Achterberg et al. (2016) is presented in Fig. 1.

According to the value hill concept, value is added while the product moves "uphill," and circular strategies keep the product at its highest value (top of the hill) for as long as possible. The circular design is one of the fundamental principles to apply during the pre-use or the design, production, and distribution phase of a product. "Tophill" is about the optimal use of resources-circular design, and sustainable consumption would be a useful tool. "Downhill" is about value recovery, which involves the post-use phase of a product. Instead of disposal of end-of-life products to landfill, the resource would be recovered during the post-use phase at the optimum level possible (uphill to downhill).

\section{The Development of Zero-Waste Concepts}

The term "zero-waste" was coined by Palmer (2004) in 1973. Since the late 1990s, the concept has attracted much public attention. Many cities around the world, such as Adelaide (Australia), Dubai (UAE), Milan (Italy), San Francisco (USA), Tokyo (Japan), Vancouver (Canada), Wales (UK), and so on, are working towards zerowaste cities. Besides, several organizations such as Adidas, Ethique, Procter \& Gamble, Subaru, Unilever, etc. have adopted the concept of zero-waste by setting zero-waste disposal targets. The Australian Capital Territory (ACT) Government released the "No Waste By 2010 - Waste Management Strategy for Canberra" in 1995, which was the first initiative that a government anywhere in the world had set such a challenging goal for waste management (Connett 2013, p. 303; Snow and Dickinson 2003, p. 5). Unfortunately, the "No Waste Bill" and the zero-waste targets were unsuccessful as the proposed implementation time (5 years) seemed to be unrealistic.

The zero-waste movement in New Zealand was started by establishing the Zero Waste New Zealand Trust in 1997 (Zaman and Ahsan 2019). The Trust voiced a goal 
Table 1 The key milestones and events on zero-waste development (Zaman and Ahsan 2019)

\begin{tabular}{|c|c|c|}
\hline Year & Country & Milestones/events \\
\hline $1970 \mathrm{~s}$ & USA & The term "zero-waste" was coined by Paul Palmer \\
\hline 1986 & USA & The National Coalition against Mass Burn Incineration was formed \\
\hline 1988 & USA & Seattle introduced the pay-as-you-throw (PAYT) system \\
\hline 1989 & USA & $\begin{array}{l}\text { The California Integrated Waste Management Act was passed to } \\
\text { achieve } 25 \% \text { waste diversion from landfills by } 1995 \text { and } 50 \% \text { by } 2000\end{array}$ \\
\hline 1990 & Sweden & Thomas Lindquist introduced the "extended producer responsibility" \\
\hline 1995 & Australia & Canberra passed the "“No Waste by 2010 " bill \\
\hline 1997 & $\begin{array}{l}\text { New Zealand, } \\
\text { USA }\end{array}$ & $\begin{array}{l}\text { The Zero Waste New Zealand Trust was established } \\
\text { The California Resource Recovery Association (CRRA) organized a } \\
\text { conference on zero-waste }\end{array}$ \\
\hline 1998 & USA & $\begin{array}{l}\text { Zero-waste was included as guiding principles in North Carolina, } \\
\text { Seattle, Washington, and Washington, DC }\end{array}$ \\
\hline 1999 & USA & The CRAA organized zero-waste conferences in San Francisco \\
\hline 2000 & USA & The Global Alliance for Incinerator Alternatives was formed \\
\hline 2001 & USA & $\begin{array}{l}\text { GrassRoots Recycling Network published "A Citizen's Agenda for } \\
\text { Zero Waste" }\end{array}$ \\
\hline 2001 & Australia & Towards Zero Waste Action Plans, WA vision for Waste 2020 \\
\hline 2002 & $\begin{array}{l}\text { New Zealand, } \\
\text { USA }\end{array}$ & $\begin{array}{l}\text { The book Cradle-to-Cradle was published } \\
\text { Zero Waste International Alliance was established } \\
\text { The first zero-waste summit was held in New Zealand }\end{array}$ \\
\hline 2004 & $\begin{array}{l}\text { Australia, } \\
\text { USA }\end{array}$ & $\begin{array}{l}\text { ZWIA gives a working definition of zero-waste } \\
\text { GRRN adopts zero-waste business principles } \\
\text { Zero Waste SA was established in South Australia }\end{array}$ \\
\hline 2008 & USA & The Sierra Club adopted a zero-waste producer responsibility policy \\
\hline 2012 & USA & $\begin{array}{l}\text { The documentary film Trashed premiered at the Cannes Film Festival } \\
\text { The Zero Waste Business Council was established in the USA }\end{array}$ \\
\hline 2017 & USA & Zero Waste Development and Expansion Act of 2017 \\
\hline 2018 & China & $\begin{array}{l}\text { From } 1 \text { January } 2018 \text {, China banned importing } 24 \text { categories of solid } \\
\text { waste. China stopped importing plastic for recycling by setting the } \\
\text { acceptable contamination level at } 0.05 \text { per cent - compared to the up } \\
\text { to } 10 \text { percent it previously accepted }\end{array}$ \\
\hline 2018 & $\begin{array}{l}\text { Global }(\mathrm{C} 40 \text {, } \\
\text { UK) }\end{array}$ & $\begin{array}{l}\text { Twenty-three global cities and regions advance towards zero-waste. } \\
\text { This commitment will avoid the disposal of at least } 87 \text { million tons of } \\
\text { waste by } 2030\end{array}$ \\
\hline 2018 & Australia & $\begin{array}{l}\text { The Australian governments set } 100 \% \text { packaging targets, i.e., } \\
\text { Australian all packaging be recyclable, compostable, or reusable by } \\
2025\end{array}$ \\
\hline 2019 & Australia & $\begin{array}{l}\text { The Australian governments has banned waste export to overseas } \\
\text { countries }\end{array}$ \\
\hline 2019 & Singapore & Singapore has designated 2019 as the year towards zero-waste \\
\hline 2020 & $\mathrm{~N} / \mathrm{A}$ & Apple's all established final assembly sites are Zero Waste certified \\
\hline 2021 & Italy & $\begin{array}{l}\text { ABB Smart Power's manufacturing in Frosinone, Italy has achieved } \\
\text { the zero waste to landfill goal }-14 \text { years ahead of the European } \\
\text { Union's Circular Economy Package target }\end{array}$ \\
\hline
\end{tabular}


of creating "a closed-loop materials economy; where products are made to be reused, repaired and recycled, an economy that minimises and ultimately eliminates waste" (Tennant-Wood 2003). In 2000, Del Norte County, California, took on the first comprehensive zero-waste plan in the USA. In 2001, the California Integrated Waste Management Board adopted zero-waste goals as strategic waste management plans (Connett 2013, p. 307). Table 1 summarizes the key milestones and events about zero-waste development.

\section{The Enigma of Consumerism, Environmental Degradation, and Zero-Waste}

Apparently, continuous technological innovation, easy access to goods and credit, low prices, online shopping, and ongoing cycles of advertising and marketing cycles all reinforce the way of life called "consumerism" (Aspin 2012, pp. 8-10). This is usually defined as a "way of life and state of mind" where activities associated with consumption become a means for establishing social position and expressing individual identity (Smart 2010, pp. 7-10). The core of our modern world's economic system is founded on the principle of consumerism of the mass population. Let us explore what we mean by consumerism and why it is essential and related to zerowaste.

In the pre-modern consumerism era, the consumption of luxurious goods and services was only available to affluent people. However, consumerism is not limited to wealthy people anymore; it is for everybody. Initial signs of consumerism include high demand for sugar in the late Middle Ages (one of the early mass consumer goods); household furnishings (beds, cloths instead of straw mattress) in the early sixteenth century; and tea and fashionable clothing at the end of the seventeenth century (Stearns 2006). According to Stearns (2006), although there was an explosion of shops and new marketing methods in the eighteenth century, which played a significant role in consumerism, it was a shopkeeper and his methods that anchored the first iteration of a consumer society (p. 16).

Shopping become an important cultural activity among the "elite" people in the eighteenth century, and the industrial revolution brought more variety in the clothes and household items and not only for the affluent elite but also for the ordinary people in the Americas and Europe (Crocker 2017; White 2009). After the postworld wars era, consumerism was mainly driven by "economic consumerism" to stimulate economic growth and ensure a good living standard (Crocker 2017, p. 10). The global economic growth model is founded on a linear material flow, i.e., "takemake-disposal" approach, whether the "planned obsolescence" is the primary principle for repetitive shopping of "waste ready" products. Planned obsolescence, i.e., designing a product for a limited useful life, is one of the biggest drivers to make products more affordable for mass people and somewhat influence economic development. Along the way, various marketing strategies and approaches such as "big is better" or "buy now pay later" were inherent in our modern consumer culture. In the 1950 s, plastics appeared to be the "magical" material to produce "waste ready" 
single-used products. It would be challenging to find a product nowadays that doesn't use plastics in the product's supply chain (Zaman and Ahsan 2019).

People are obsessed with changing or upgrading their "almost new" gadgets because there is a newer and a little more "fancier" version available. However, both would perform similar or identical functionality. People find "pleasure" in consumption and try to establish a social identity in a diminished social value system. On the contrary, economic growth doesn't always ensure a similar level of human subjective well-being as promised to deliver. The current overconsumption trends are mainly driven by technological innovation, fashion, deferral pricing, corporations, branding, and marketing strategies (Crocker 2013; Princen et al. 2002; Slade 2006). Over time, these influential factors contribute to product obsolescence and repetitive consumption practices, which are the core cause of generating excessive waste and depleting natural resources.

Clothing is an excellent example of how consumer culture significantly impacts the environment. Like America and Europe, Australia's obsession with new clothes and "fast fashion" textiles is hurting the environment significantly like America and Europe. Australia's obsession with new clothes and "fast fashion" textiles seriously hurts the environment (Pepper 2017). A T-shirt retails in America often travels over 10,000 miles, and most of the distance (88\%) travels during the production (mainly in Asia) and distribution phases (Xing et al. 2016). As consumers, very few of us truly realize how our consumption choice, even for a single T-shirt, impacts people's livelihood and the environment in the distant parts of the world.

On average, Australians dispose 6000 kilograms of fashion and textile waste every 10 minutes. Only $15 \%$ of it is sold again locally in opportunity shops, and the rest $85 \%$ ends up in landfills (Wynne 2017). The moment we throw our clothes and consumer goods into the waste bins, it becomes somebody else's problem. The realization of the impacts from waste through greenhouse gas and leachate contamination in landfills is not easy and fun to do.

Given various contexts, how does zero-waste tackle these challenges? The zerowaste concept recognizes that the current linear economic model which is based on consumer culture is not sustainable. Thus, an alternative economic model such as a circular economy model is necessary, which will ensure "custodian citizen" to promote sustainable consumption, material circularity, and conserve the natural environment. Since zero-waste identifies waste as materials in transition, it favors the repetitive use of resources instead of burning and burying forever. The following sections present the zero-waste practices worldwide from an individual level to a city level.

\section{Zero-Waste Practices Around the World}

\section{Zero-Waste Family}

We have seen several occasions where people or a family live without producing a notable amount of "waste." Although most cases are published through social media and blog, they can be regarded as aspirations that people are trying to achieve after 
realizing how our way of life is depleting the environment. Some families in California (Johnson 2013), Phoenix (Mlynek 2018) in the USA, and Tasmania in Australia and many other places in the world are trying to live without creating any waste. In all these families, one thing is common: they have embraced the zero-waste challenge and are working towards the aspirational zero-waste goals. Bea Johnson and her family, living in Mill Valley, California, USA, is one of the most renowned zero-waste practitioners in social media who has adopted the zero-waste lifestyle since 2008. After living a decade on the zero-waste lifestyle, the outcome is extraordinary concerning well-being, and she states, "We not only feel happier, but we also lead more meaningful lives based on experiences instead of stuff" (Zero Waste Home 2018).

Zero-waste practices in families worldwide give a mixed message (needs to be vegan, sacrificing lifestyle, etc.) because the practitioners maintain different enthusiasm levels considering the practicality under the current system. Zero-waste requires transforming our existing system concerning product design and shopping system, which is not entirely equipped to achieve zero-waste goals. Thus, under the current situation, zero-waste practices could mean differently to families. Moving towards zero-waste lifestyles requires individual or family commitments and the necessary supporting infrastructure, for example, packaging-free bulk grocery shops. In recent years, packaging-free zero-waste shops are growing in numbers in many cities.

The most common practices that the zero-waste families are conducting are:

- Focusing on needs instead of desire when it comes to consumption and shopping

- Avoid shopping single-used goods (bottled water, bags, utensils, etc.)

- Avoid shopping goods with unnecessary packaging and buy bulk with reusable/ refillable bottles/jars and from local growers

- Reuse non-compostable items such as jars, bottles, cloths, etc. as much as possible

- Mindful about what to buy and how it would contribute to waste generation and seek alternatives

- Recycle whatever cannot be reused

- Composting all organic materials in the household

Considering only municipal solid waste, achieving zero waste goals would be tough and challenging to achieve zero-waste goals, even though several families have shown how they live by creating only a jarful of waste in a year instead of three different bins full of waste every week. However, it is also essential to acknowledge that they achieved that because of their extreme dedication and desire to change their lifestyle, which may not be valid for mass people. It is also expected that almost all notable zero-waste families live in stand-alone houses with gardening and composting facilities. It may not be possible to maintain the same outcome if one lives in an apartment block without any composting facility. This affirms that 
systemic changes in personal, social, and infrastructural are needed to achieve the zero-waste goals.

\section{Kamikatsu, Japan: A Zero-Waste Community}

\section{Kamikatsu Community}

Kamikatsu is a small town in Japan located in Katsuura District. Kamikatsu is hilly and dominated by a range of mountains higher than 1000 meters above sea level. A total of 1556 people (in 2018) live in 788 households with a higher ratio of female than male (1:1.1) (Kamikatsu 2018). Over half (50.3) of the population is over 65 years old, and one-quarter of the population is over 85 years old (Suzuki, 2018). There is no formal door-to-door waste collection system from the local authority; thus, the local community is responsible for collecting and managing their waste.

Although waste was predominantly managed through open burning, the restriction of open burning and the mandate for recycling in the early 1990s forced the local community to sort recyclable from non-recyclable. Even the waste-to-energy plant was shut down due to a high level of dioxin pollution and to meet Japan's pollution reduction target, encouraging the community to look for an alternative solution to manage waste more sustainably. In 2003, Kamikatsu considered zero-waste as part of its waste management policy, aiming to be a $100 \%$ zero-waste town by 2020 (Sakano 2017).

Table 2 The key waste management milestones at Kamikatsu. (Adapted from ZWA (2018) with permission)

\begin{tabular}{l|l|l}
\hline Year & Options & Brief descriptions \\
\hline $\begin{array}{l}\text { Before } \\
1990 \mathrm{~s}\end{array}$ & $\begin{array}{l}\text { Informal disposal/open } \\
\text { burning }\end{array}$ & $\begin{array}{l}\text { The absence of formal waste collection leads to open } \\
\text { burning and informal disposal of household waste }\end{array}$ \\
\hline $1991-1995$ & $\begin{array}{l}\text { Open incineration with } \\
\text { alternative options }\end{array}$ & $\begin{array}{l}\text { Subsidies for the household composter, formation of } \\
\text { the Kamikatsu Recycle Town Plan, along with open } \\
\text { incineration }\end{array}$ \\
\hline 1997 & $\begin{array}{l}\text { 9 segregation } \\
\text { categories }\end{array}$ & $\begin{array}{l}\text { Commenced separate collection of wastes under the } \\
\text { National Recycling Act (clear, brown, and other } \\
\text { colored glass bottles, aluminum cans, steel cans, spray } \\
\text { cans, milk cartons, incineration waste, bulk waste) }\end{array}$ \\
\hline 1998-2000 & $\begin{array}{l}\text { 22 segregation } \\
\text { categories }\end{array}$ & $\begin{array}{l}\text { Concern about dioxin pollution from the incineration } \\
\text { and increasing the sorting categories from 9 to 22 }\end{array}$ \\
\hline 34 waste categories & $\begin{array}{l}\text { Shut down small incinerators and increase sorting } \\
\text { categories from 22 to 34 to improve recycling } \\
\text { efficiency. Volunteer group "Recycle Kamikatsu" } \\
\text { helped transport waste from households to the } \\
\text { collection center }\end{array}$ \\
\hline $2016-2017$ & $\begin{array}{l}45 \text { segregation } \\
\text { categories }\end{array}$ & $\begin{array}{l}\text { Renewed the Resource Segregation Guidebook for } \\
\text { residents Established the Zero Waste Accreditation } \\
\text { system }\end{array}$ \\
\hline
\end{tabular}




\section{Kamikatsu Zero-Waste Declaration}

Kamikatsu was one of the first towns in Japan to declare the zero-waste goal in 2003. The aspects of Kamikatsu Zero Waste Declaration are (ZWA 2018):

- Kamikatsu will strive to foster ecologically conscience individuals.

- Kamikatsu shall promote waste recycling and reusable resources to the best of its ability for eliminating waste incineration and landfill by 2020.

- Residents of Kamikatsu shall join hands with people around the world for ensuring a sustainable global environment (Table 2).

\section{Zero-Waste Practices at the Kamikatsu Community}

Zero Waste Academy (ZWA) is a local organization working towards achieving zero-waste goals by changing people's mindsets, actions, and social systems to make zero-waste Kamikatsu (Sakano 2017). Under the zero-waste strategies, 100\% of all organic waste is composted at home either with the traditional home composting method or an electric composting machine. The local government subsidizes the composting devices' cost as this will help reduce organic waste volume. Each household and store are responsible for washing, sorting, and delivering their trash to the recycling center (Hibigaya Waste Station) (Fig. 2).

Household waste sorting is one of the biggest challenges to recovering materials from waste. In many countries and cities in Europe and North Americas, waste is sorted into several categories: paper, plastics, metals, glass, electronic waste, organic waste, etc., depending on the local management infrastructure's availability. Local people at Kamikatsu sorted waste into 45 different categories (Sturmer 2018). There are 13 main categories, and under each category, there are several subcategories to sort waste based on their characteristics. For example, cans are subcategorized as aluminum, steel, and spraying cans; glass bottles are subcategorized as clear, brown,

Fig. 2 Sorting options for various resource types at the waste station. (Courtesy: Akira Sakano, Zero Waste Academy, Japan)

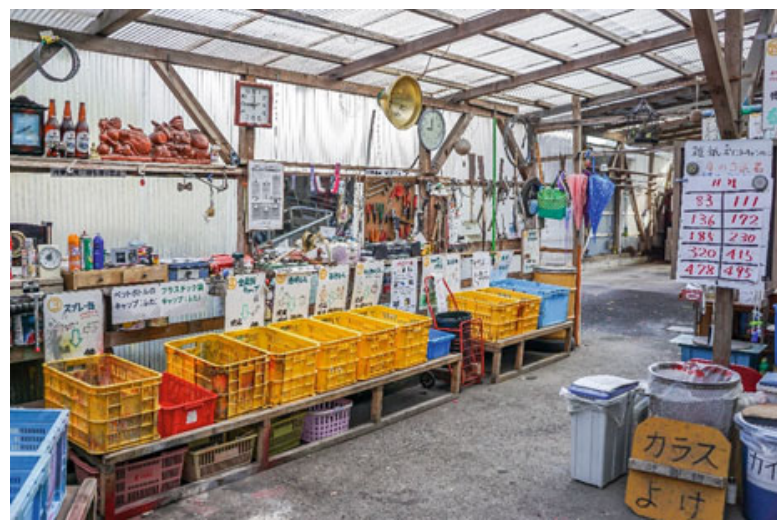


Table 3 Waste sorting categories at Kamikatsu

\begin{tabular}{|c|c|c|c|}
\hline Number & $\begin{array}{l}\text { Main waste sorting } \\
\text { categories }\end{array}$ & Waste sorting subcategories & Potential use \\
\hline 1 & Reusable & Reusable items & Second-hand shop \\
\hline 2 & Organic & Organic waste & Home composting \\
\hline 3 & Metals & $\begin{array}{l}\text { Aluminum cans } \\
\text { Steel cans } \\
\text { Spray cans } \\
\text { Metal cans } \\
\text { Scrap metals }\end{array}$ & $\begin{array}{l}\text { Aluminum products } \\
\text { Steel products } \\
\text { Metal products } \\
\text { Metal products } \\
\text { Metal products }\end{array}$ \\
\hline 4 & Papers & $\begin{array}{l}\text { Newspaper flyers } \\
\text { Cardboards } \\
\text { Magazine scrap paper } \\
\text { Paper cups } \\
\text { Paper carton with aluminum } \\
\text { Hard paper core } \\
\text { Shredded papers } \\
\text { Other papers }\end{array}$ & $\begin{array}{l}\text { Newspaper } \\
\text { Cardboards } \\
\text { Recycled paper } \\
\text { Recycled paper } \\
\text { Recycled paper } \\
\text { Cardboards } \\
\text { Recycled paper } \\
\text { Refuse paper and plastic } \\
\text { fuel (RPF) }\end{array}$ \\
\hline 5 & Cloths & $\begin{array}{l}\text { Biodegradable cloths } \\
\text { Other cloths }\end{array}$ & $\begin{array}{l}\text { Second-hand shops } \\
\text { RPF }\end{array}$ \\
\hline 6 & Firewood/fuel & $\begin{array}{l}\text { Chopsticks wood } \\
\text { Master oil }\end{array}$ & $\begin{array}{l}\text { RPF } \\
\text { Compost fodder }\end{array}$ \\
\hline 7 & Plastics & $\begin{array}{l}\text { Clean plastic packaging } \\
\text { Dirt plastic packaging } \\
\text { (squeezy pack) } \\
\text { Styrofoam trays (white) } \\
\text { Styrofoam } \\
\text { PET bottles } \\
\text { PET bottle caps }\end{array}$ & $\begin{array}{l}\text { Plastic products, RPF } \\
\text { RPF } \\
\text { Styrofoam trays } \\
\text { RPF } \\
\text { Cloths } \\
\text { Plastic products/RPF }\end{array}$ \\
\hline 8 & Glass & $\begin{array}{l}\text { Clear glass bottle } \\
\text { Brown glass bottles } \\
\text { Other colored bottles } \\
\text { Reusable glass bottles }\end{array}$ & $\begin{array}{l}\text { Clear glass bottles } \\
\text { Brown glass bottles } \\
\text { Glass bottles } \\
\text { Reuse }\end{array}$ \\
\hline 9 & Mixed product & $\begin{array}{l}\text { Other glass, potteries } \\
\text { Mirrors, thermometer } \\
\text { Light bulb, fluorescent tubes } \\
\text { Dry batteries } \\
\text { Discarded batteries } \\
\text { Lighters }\end{array}$ & $\begin{array}{l}\text { Based course material } \\
\text { Mercury \& glass wool } \\
\text { Mercury \& glass wool } \\
\text { Metal products } \\
\text { Lead } \\
\text { Metal products }\end{array}$ \\
\hline 10 & Bulk products & $\begin{array}{l}\text { Large metal products } \\
\text { Bulk wooden product } \\
\text { Beddings, mattress, etc. } \\
\text { Large/bulk PVC/rubber } \\
\text { products }\end{array}$ & $\begin{array}{l}\text { Metals } \\
\text { RPF } \\
\text { RPF } \\
\text { Incineration }\end{array}$ \\
\hline 11 & Mixed items & $\begin{array}{l}\text { PVC, leather products, etc. } \\
\text { Diapers and sanitary } \\
\text { napkins }\end{array}$ & $\begin{array}{l}\text { Incineration } \\
\text { Incineration }\end{array}$ \\
\hline 12 & Shells & Shells & Landfill \\
\hline 13 & Home appliances & $\begin{array}{l}\text { Discarded tires } \\
\text { Specific home appliances }\end{array}$ & $\begin{array}{l}\text { RPF } \\
\text { Recycled by each } \\
\text { producer/brand }\end{array}$ \\
\hline
\end{tabular}


other, and returnable glass bottles. These subcategories require a higher level of knowledge and understating of waste sorting and recycling issues to recycle correctly. Table 3 shows the waste categories at Kamikatsu.

All individuals in the community are responsible for taking their waste to the recycling center. A significant proportion of the community is very elderly people, and an intermitted waste collection system is offered once every two months. The local community needs to sort their non-organic waste into 45 different categories. Still, they also need to meet the recycling requirement, such as properly sorting, cleaned, and dried, which is also true for the residents outside of Kamikatsu. If waste is not properly cleaned and separated, it is not picked up (Sturmer 2018). After 15 years of implementation of the zero-waste practices in Kamikatsu, the town currently recycles around $80 \%$ of its waste, and the remaining $20 \%$ that can't now be processed - things like nappies and certain types of plastics - gets sent off to be incinerated (Garfield 2018; Sturmer 2018).

At the beginning of the zero-waste program, the community found the zero-waste practices were challenging and time-consuming. A survey in 2008 showed that around $40 \%$ of residents were still unhappy about at least one aspect of the zerowaste policy, which is washing each recyclable item before sending it to the recycling center (McCurry 2008), which has become a norm after a decade-long practice. According to Akira Sakano, Chair, the Board of Directors of the Zero Waste Academy, the sheer inconvenience of the process can act as a deterrent to excess consumption in the first place. The detailed categorization can make people start thinking about what they should buy, how much, and when, i.e., beginning of the problem (Garfield 2018).

\section{Zero-Waste Business}

\section{Adidas: Zero-Waste Sporting Project}

As part of its sustainability initiative, Adidas has partnered with "Parley for the Oceans" - an organization working for the ocean's ecosystem. Adidas launched a zero-waste sporting project called "Sport Infinity" in 2015 with a plan for a new breed of sporting goods that will never be thrown away. The Sports Infinity project has the potential to be recycled endlessly and combined into new products through a closed-loop supply chain of sports products (Adidas-Group 2015).

Adidas-Parley's AIR approach is to avoid (A) through reducing and replacing materials with sustainable ones, intercept (I) through retrieving and recycling problematic materials such as plastic waste from the ocean, and redesign (R) through creating a new industry standard (Parley 2018). In 2016, around 740 tons of plastic pollution were collected by the partnership organization "Parley for the Oceans" from the Maldives, Indian Ocean, to turn plastic waste into yarn (Parley 2018) (Fig. 3).

The recycled plastic yarn is used to produce shoes and t-shirts, and the target was to produce one million shoes using ocean plastic (McCarthy 2018). Each pair of 


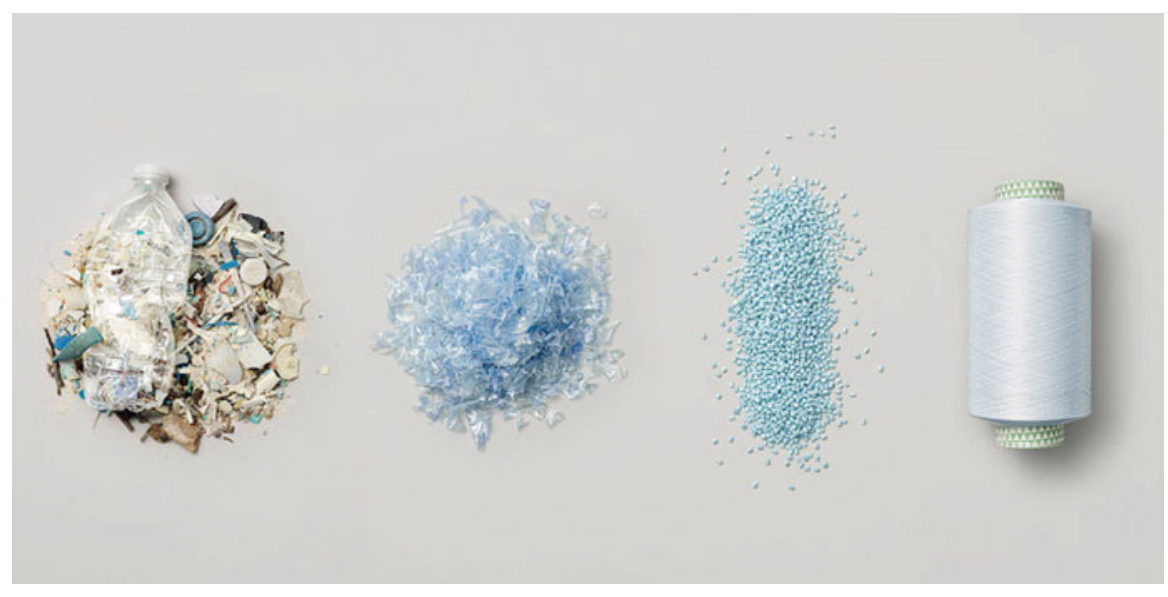

Fig. 3 Converting ocean plastic into yarn. (Parley (2018), with permission)

sneakers takes 11 plastic bottles to make, which could mean that Adidas will recycle 55 million plastic bottles in 2018 if they hit their projected sales. Adidas wants to make all products from recycled plastic by 2024 (WMC 2018). Adidas has started to produce shoes made from reclaimed and recycled ocean trash (Borchardt 2017).

\section{The Zero-Waste Stores to Phase -Out Unnecessary Packaging}

In recent years, zero-waste stores have been opened up aiming to minimize the environmental impact by phasing out unnecessary packaging (Moss 2019). Plastics waste seems to be one of the biggest environmental changes for humanity due to its adverse pollution to the environment. However, unnecessary packaging is a common practice that can be easily avoided through zero-waste thinking. Over $36 \%$ of all plastics are used for packaging (Geyer et al. 2017); therefore, reducing and phasing out unnecessary plastics packaging through zero-waste make more sense than the traditional business model. Understandably, people who would like to implement zero-waste practice in everyday life need the necessary support infrastructure, such as zero-waste stores within their close proximity. The zero-waste shops offer consumers reusable containers and refill the required products ranging from oil and shampoo to cereals. A significant proportion of packing waste can be avoided through these alternative shopping practices. Another benefit of buying unpackaged items from the zero-waste store is that one can buy the amount the person or the family needs, which may not always be the case for prepacked supermarket stores. As a result, a significant proportion of foods and groceries are wasted in households due to over-shopping. Figure 4 shows an example of unnecessary packaging (left) and a zero-waste shop. 

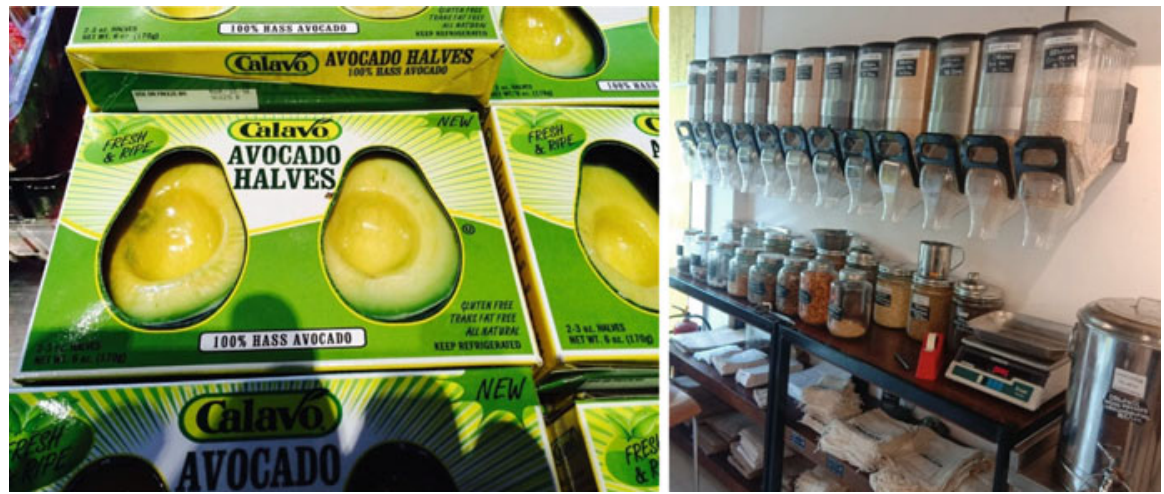

Fig. 4 The examples of unnecessary packaging (left) and zero-waste shop (right). (Sources: Flickr Creative Commons)

\section{Zero-Waste City: The Case Study of San Francisco, USA}

\section{Waste Management in San Francisco}

San Francisco is one of the world's leading cities that has considered zero-waste as its core waste management manifesto. In the UN-HABITAT (2010) study of solid waste management in the world's cities, San Francisco has been identified as one of the most resourceful cities in waste management services. However, San Francisco has a long history in waste collection systems, from informal waste recycling in the early twentieth century to today's modern collection systems. Homeless and jobless poor people mostly drove informal recycling in the early 1930s as a means of survival. This was also seen in the last global economic crisis in 2008-2012. San Francisco has successfully transformed its waste management system by integrating informal waste recycling activities with formal waste management systems.

The composition of MSW waste in San Francisco includes organic (34\%), paper $(24 \%)$, plastic (11\%), glass (3\%), metal (4\%), and miscellaneous $(24 \%)$. Household hazardous waste is included in municipal waste, and, therefore, hazardous waste is also managed by the local waste management authority. A total of 508,323 tons of MSW (609 kg per person per year) was generated in 2008, making San Francisco one of the world's highest waste-generating cities. MSW is primarily managed by recycling (52\%) and composting (20\%), and the remainder of the waste $(28 \%)$ is managed by landfills. The landfill waste in San Francisco has consisted of 31\% organics, $23 \%$ paper, $23 \%$ C\&D, and 23\% other inert (SF Environment 2019), which indicates that with a proper system, the recycling rate can be improved further.

Over time, San Francisco has adopted various policies and strategies around waste management and zero-waste. In regard to waste services, San Francisco predominantly depends on a single service provider. Recology collects waste from households and public waste bins and transports it to the central material recovery 


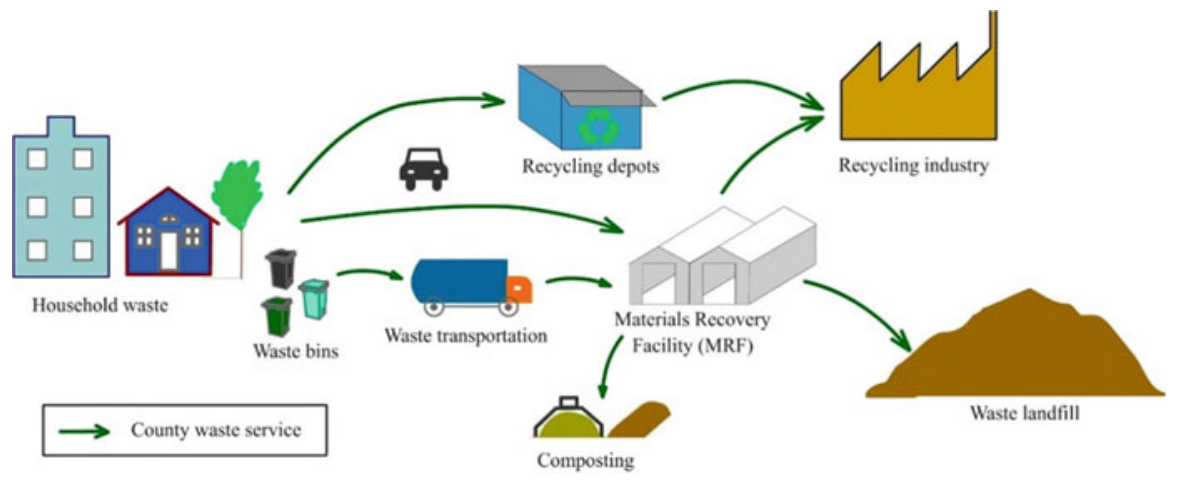

Fig. 5 The material flow of waste management systems in San Francisco

facility (MRF). Figure 5 shows the schematic waste management systems in San Francisco.

\section{Regulatory Policies and Zero-Waste Strategies}

San Francisco has an effective and successful implementation of waste management policies and strategies. The notable policy can be outlined back to the Scavengers Protective Union's formation in 1879 (Perry 1978, p. 19). Since the nineteenth century, San Francisco has been visionary and supportive of environmentally friendly solutions. Thus, in 1987 the community opposed incinerator as a solution, instead enforcing community recycling and curbside collection systems. In 1988, San Francisco set a 32\% reduction in the city's waste stream by 1992 and $43 \%$ by 2002 (US-EPA 1993).

The sustainable waste management strategy in San Francisco started in 2005 when the city initiated the UN Urban Environmental Accords, which include zerowaste, manufacturer responsibility, and consumer responsibility under the Waste Reduction Accord (City of Berkley 2005). San Francisco has adopted a range of regulatory policies to ensure maximum resource recovery from waste by integrating many stakeholders' involvement, including local businesses, local governments, and communities.

The first zero-waste strategy was adopted in 2005 under the Urban Environmental Accords to achieve a waste-free city by 2020 . As a result, San Francisco achieved an $80 \%$ diversion rate (residential and commercial) and $61 \%$ diversion rate (equivalent to Germany's 62\%) of municipal solid waste in 2012 (MacBride 2013). Undoubtedly, achieving zero-waste in the future is an ambitious target. It involves product manufacturers and consumers to ensure that all discarded materials are diverted from landfill. Realizing the challenges of zero-waste, San Francisco updated the zero-waste goal at the Global Climate Action Summit, in September 2018, to these two pledges: 
Table 4 Key milestones of municipal waste management systems in San Francisco

\begin{tabular}{|c|c|c|}
\hline Year & Milestones in WMS & Goal and focus \\
\hline 1879 & Scavengers Protective Union & $\begin{array}{l}\text { The union protects the scavengers' right and promotes } \\
\text { recycling }\end{array}$ \\
\hline 1932 & $\begin{array}{l}\text { Refuse Collection and } \\
\text { Disposal Initiative Ordinance }\end{array}$ & $\begin{array}{l}\text { Waste collected only by license holder: waste service } \\
\text { provider (Recology) }\end{array}$ \\
\hline 1970 & Community recycling center & $\begin{array}{l}\text { Community recycling centers promote recycling } \\
\text { activities within the city and involve local people }\end{array}$ \\
\hline 1981 & Curbside waste collection & $\begin{array}{l}\text { Collect recyclables from the community by the } \\
\text { systematic curbside collection system }\end{array}$ \\
\hline 1987 & $\begin{array}{l}\text { Suspension of Incineration } \\
\text { Plant }\end{array}$ & $\begin{array}{l}\text { Incinerator for waste management deferred due to } \\
\text { environmental pollution }\end{array}$ \\
\hline 1988 & Waste Diversion Targets & $\begin{array}{l}\text { Visionary diversion targets for higher recycling and } \\
\text { less landfill }\end{array}$ \\
\hline 2003 & $\begin{array}{l}\text { Extended Producer } \\
\text { Responsibility Resolution }\end{array}$ & $\begin{array}{l}\text { Ensure producers' responsibility on the end-of-life } \\
\text { product }\end{array}$ \\
\hline 2004 & Fantastic Three Program & Promote higher sorting efficiency and recycling rate \\
\hline 2004 & Green Building Ordinance & $\begin{array}{l}\text { Requires city construction to manage waste and } \\
\text { provide adequate recycling storage space in buildings }\end{array}$ \\
\hline 2005 & $\begin{array}{l}\text { Urban Environmental } \\
\text { Accords }\end{array}$ & $\begin{array}{l}\text { Visionary zero-waste strategy, producer, and } \\
\text { consumer responsibility }\end{array}$ \\
\hline 2006 & $\begin{array}{l}\text { C\&D Debris Recovery } \\
\text { Ordinance }\end{array}$ & $\begin{array}{l}\text { Requires C\&D projects to use city-registered } \\
\text { transporters and processing facilities to increase debris } \\
\text { recovery }\end{array}$ \\
\hline 2006 & $\begin{array}{l}\text { Food Waste Reduction } \\
\text { Ordinance (extended in } \\
\text { 2016) }\end{array}$ & $\begin{array}{l}\text { Requires restaurants and food vendors to not use } \\
\text { Styrofoam food service ware and instead use } \\
\text { foodware that is recyclable or compostable }\end{array}$ \\
\hline 2007 & $\begin{array}{l}\text { Plastic Bag Reduction } \\
\text { Ordinance }\end{array}$ & $\begin{array}{l}\text { Requires the use of compostable plastic, recyclable } \\
\text { paper, and/or reusable checkout bags by supermarkets } \\
\text { and drugstores }\end{array}$ \\
\hline 2010 & $\begin{array}{l}\text { Mandatory Recycling and } \\
\text { Composting Ordinance }\end{array}$ & $\begin{array}{l}\text { Everyone is required to separate and put their } \\
\text { recycling, composting, and trash in the right place }\end{array}$ \\
\hline 2010 & $\begin{array}{l}\text { The Alameda County } \\
\text { Landfill Ban }\end{array}$ & $\begin{array}{l}\text { Alameda does not receive any contaminated } \\
\text { recyclables to promote recycling and zero-waste }\end{array}$ \\
\hline 2012 & $\begin{array}{l}\text { Extended Bag Reduction } \\
\text { Ordinance }\end{array}$ & $\begin{array}{l}\text { Reduction of single-use plastic bags and promotion of } \\
\text { reusable shopping bags }\end{array}$ \\
\hline 2014 & Bottled water legislation & $\begin{array}{l}\text { Restricted sale or distribution of drinking water in } \\
\text { plastic bottles of } 21 \text { ounces or less on city property }\end{array}$ \\
\hline $\begin{array}{l}2018 \\
2019\end{array}$ & $\begin{array}{l}\text { Plastics, Toxics, and Litter } \\
\text { Reduction Ordinance }\end{array}$ & $\begin{array}{l}\text { The Single-Use Foodware Plastics, Toxics, and Litter } \\
\text { Reduction Ordinance aims to: } \\
\text { Reduce plastic pollution by prohibiting the } \\
\text { distribution of plastic straws, among other foodware } \\
\text { accessories, and providing allowed accessories only } \\
\text { upon request } \\
\text { Eliminate toxic fluorinated chemicals from } \\
\text { foodware products }\end{array}$ \\
\hline 2019 & Zero-waste events & $\begin{array}{l}\text { The event producers in San Francisco must do at least } \\
\text { one of the following: } \\
\text { Provide, lend, or sell reusable beverage cups to } \\
\text { event attendees } \\
\text { Promote or incentivize attendees to bring their own } \\
\text { reusable beverage cup }\end{array}$ \\
\hline
\end{tabular}


Table 4 (continued)

\begin{tabular}{l|l|l}
\hline Year & Milestones in WMS & Goal and focus \\
\hline 2020 & Compostable foodware & Starting 1 January 2020, straws made of natural fiber \\
& requirements & or paper and all other compostable foodware sold in \\
& & San Francisco must be certified by the Biodegradable \\
& & Products Institute (BPI). Examples of compostable \\
& & foodware include: \\
& & Grease-resistant paper \\
& & Paper plates \\
& & To-go containers and straws made of paper or other \\
& & natural fiber
\end{tabular}

- Reduce municipal solid waste generation by $15 \%$ by 2030 (reducing recycling, composting, and trash)

- Reduce disposal to landfill and incineration by $50 \%$ by 2030 (reducing what goes in the black trash bins)

Table 4 shows the critical milestones of municipal waste management policies and strategies in San Francisco

One of the critical zero-waste drivers for San Francisco is the city's strong commitment to the precautionary principle and visionary strategies. Various regulatory policies and strategies have shaped the current waste management performance, such as Refuse Collection and Disposal Initiative Ordinance, curbside collection, Fantastic Three Program, landfill ban, food and plastic waste reduction, and so on. The zero-waste challenge in San Francisco is reflected in the solid waste systems support for reducing consumption, maximizing diversion, and encouraging reuse, repair, and green purchasing. Banning troublesome goods such as plastic bags and superfluous packaging and promoting alternatives such as recyclable or compostable takeout food packaging and reusable transport packaging are the most prominent initiatives for achieving zero-waste goals in San Francisco (UN-HABITAT 2010).

\section{Implementation of the Zero-Waste Strategies}

Based on the discussion presented above of various waste management challenges and by analyzing the current zero-waste practices in family, business, and urban scale, this chapter proposes several zero-waste strategies and exemplary action plans which could be useful to implement zero-waste principles. The listed strategic elements presented in the below table were identified in the author's previous study (Zaman 2017) through a perception survey of the waste experts. Table 5 summarizes the guiding principles as the zero-waste framework elements (in no particular order). Four selected groups of stakeholders (national and state governments, local government, community and family, and industry) are analyzed based on their relevance and importance (low, medium, and high) of the action plans in Table 5. 


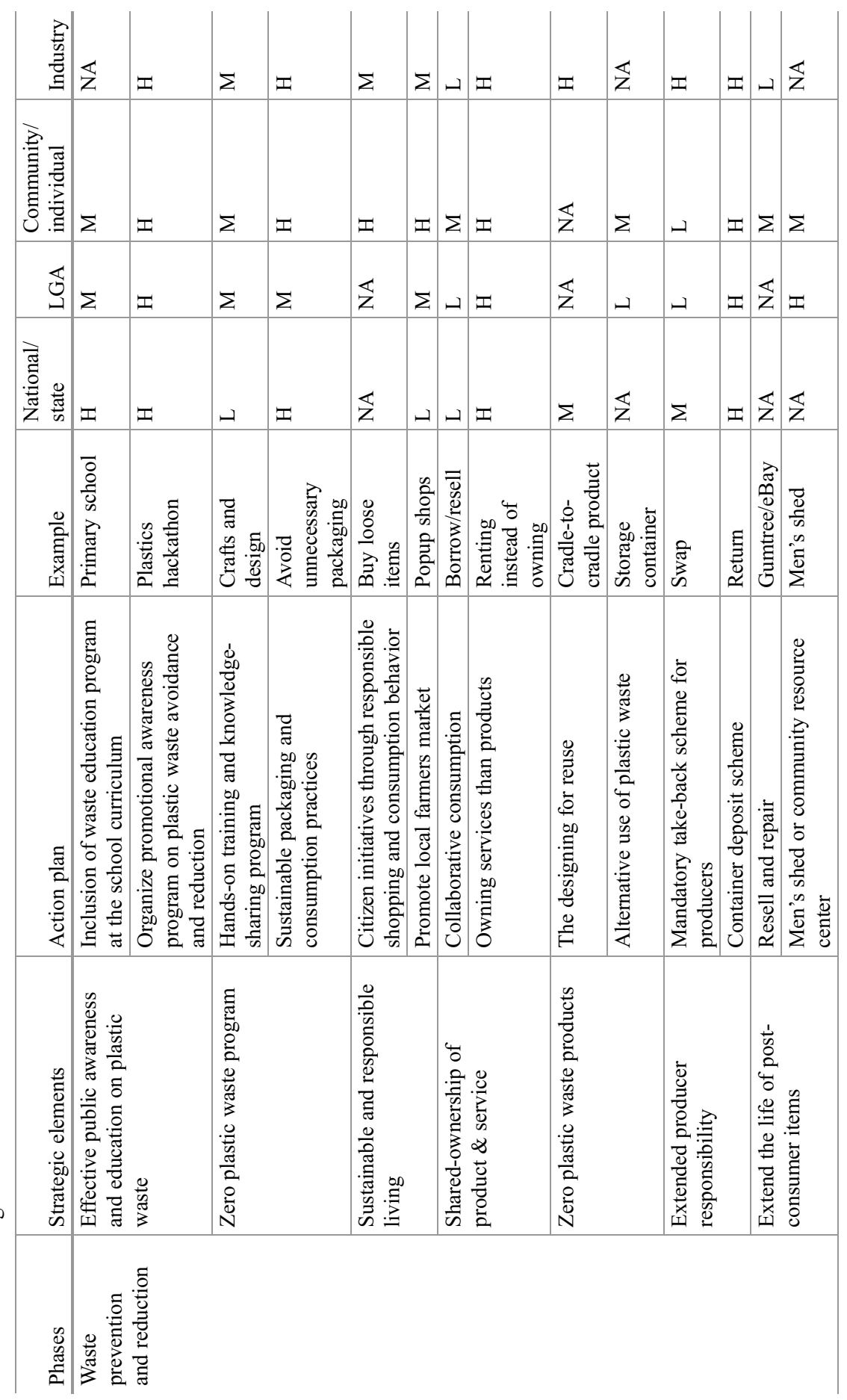




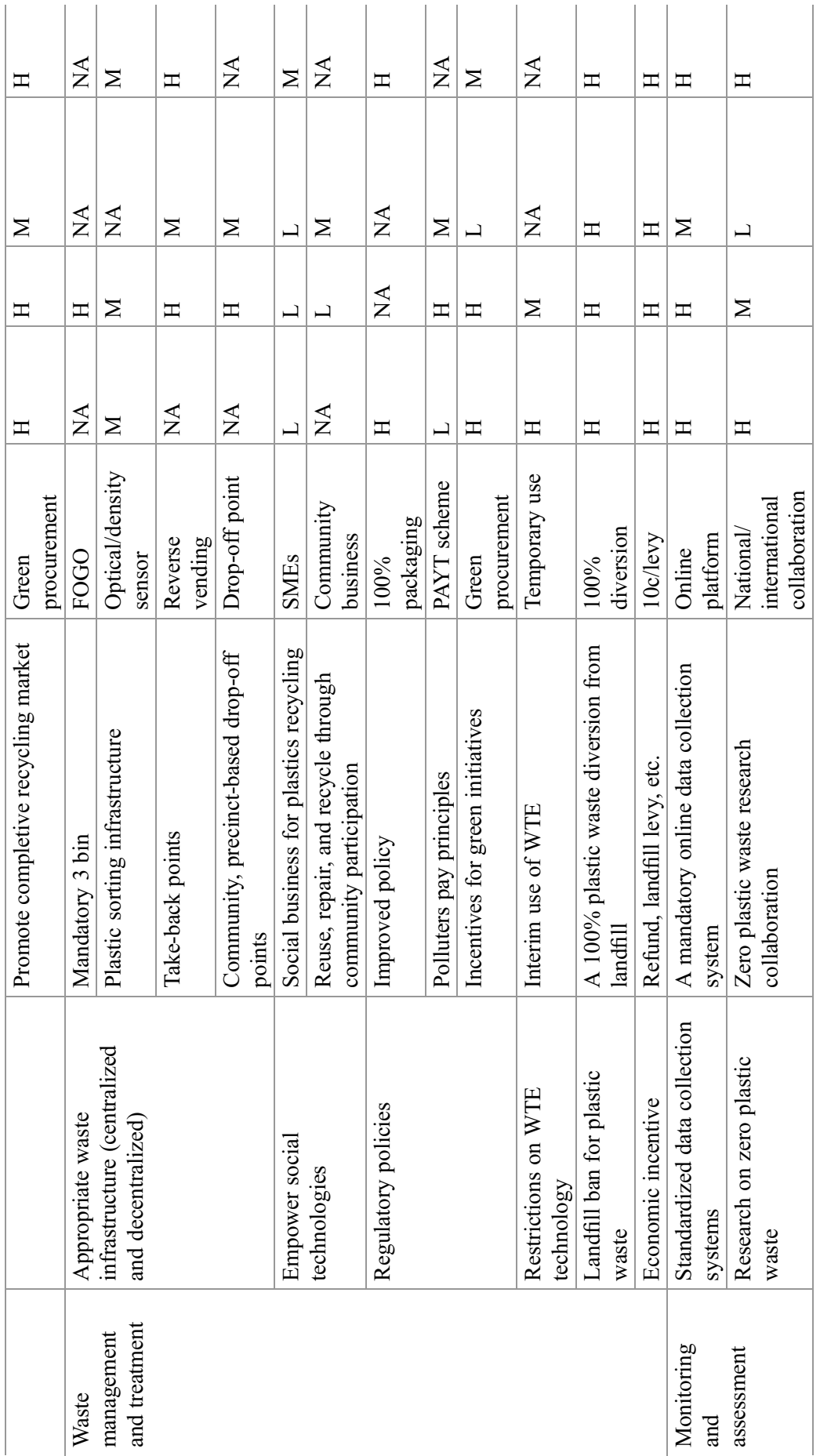


Fig. 6 Steps in the zerowaste action plan (Zaman 2017)

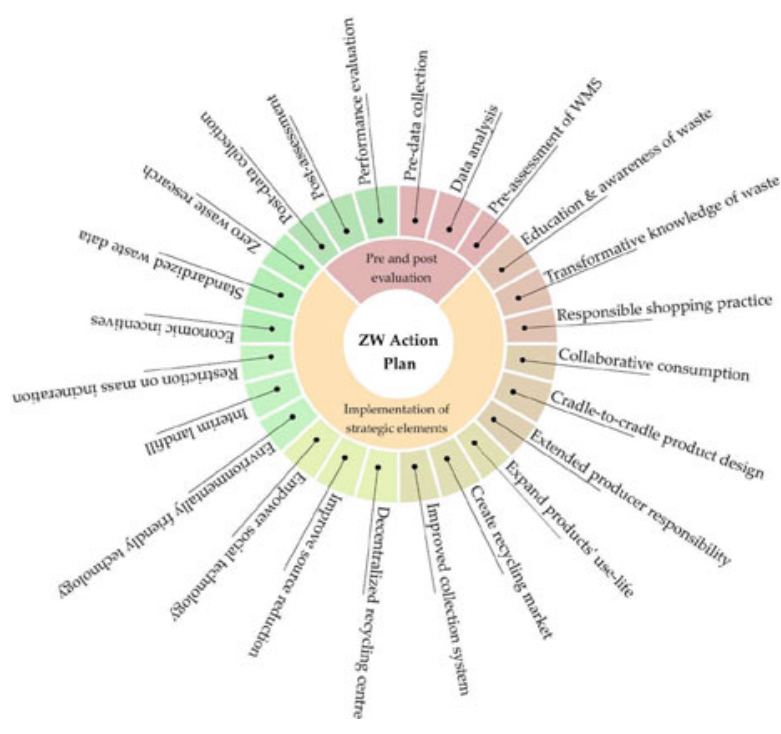

Table 5 presents overarching zero-waste strategies in the context of the relevance for various stakeholders. It is apparent from Table 5 that the local governments seem to be the most relevant, followed by industry and local community and individuals. It is important to acknowledge that the proposed strategic elements and action plans are contextual and may not be applicable to all countries, especially in both developed and developing countries. Thus, the development and application of zero-waste strategies need an explicit consideration of the locality's local needs and priority areas. The strategic elements should be implemented by following both short-term (i.e., 5-10 years) and long-term (i.e., over 10 years) action plans. Cities that consider zero-waste practices worldwide indicate that achieving a $60-80 \%$ waste diversion from landfills is achievable within a short period of time. San Francisco (USA), for example, diverted $80 \%$ of the waste from landfills in 7 years (2005-2012), and Novara (Italy) achieved a 70\% diversion rate within 18 months when the zero-waste program was initiated (Connett 2010). However, diverting the remaining 30\%-20\% of waste from landfills is the biggest challenge because of inappropriate design and poor recycling practices. Therefore, appropriate product design and responsible consumption and recycling behavior are crucial for achieving a $100 \%$ waste diversion rate.

Three steps (clockwise) of implementing action plans are presented in Fig. 6, which are (i) pre-assessment or evaluation of waste management system for benchmarking, (ii) implementing zero-waste programs, and (iii) post-evaluation of the waste management performance against benchmarking study. 


\section{Conclusion}

The vision for zero-waste and zero-waste cities is not only a new sustainability paradigm for addressing the global waste problem, but at the same time, it is also very challenging to achieve. Zero-waste requires a long-term commitment and active participation from all relevant stakeholders including producers, consumers, and regulatory bodies. Similar to climate change issues, the skeptic would have different views on the zero-waste agenda. However, implementing zero-waste practices seems beneficial not only for the environmental aspects and for creating new business and economic momentum. Already global 23 cities (C40 Cities 2020) pledge to advance towards zero-waste cities by:

- Reducing the municipal solid waste generation per capita by at least $15 \%$ by 2030 compared to 2015

- Reducing the amount of municipal solid waste disposed to landfill and incineration by at least $50 \%$ by 2030 compared to 2015 and increasing the diversion rate away from landfill and incineration to at least $70 \%$ by 2030

The change is inevitable as the pollution from waste is significantly damaging to the environment. Education and awareness are the first aspects of working towards zero-waste. The second crucial aspect is the industrial transformation of product design and manufacturing. In recent years an influx of global initiatives has been observed mainly to tackle plastic packaging waste. Andrew Forrest (mining giant in Australia and the founder of Minderoo Foundation) has committed to USD 300 million and several big companies to end worldwide plastic waste (Minderoo Foundation 2019). Similar initiatives and commitments are needed from the world-leading manufacturers and retail brands. Finally, global citizens' role is also an essential aspect because zero-waste is not about managing the waste, but mainly about not creating it in the first place during the consumption process. Therefore, without responsible global stewardship, the visionary zero-waste goals can never be achieved.

\section{References}

Achterberg E., Hinfelaar, J., \& Bocken, N. M. P. (2016). Master Circular Business with the Value Hill. Circle Economy, Nuovalente, Sustainable Finance Lab and TU Delft. https://www.circleeconomy.com/wp-content/uploads/2016/09/finance-white-paper-20160923.pdf

Adidas-Group. (2015). Messi's boots today, recycled into yours tomorrow. Retrieved from https:// www.adidas-group.com/media/filer_public/51/cd/51cd8d06-a718-4445-a4e7-5fa99d601424/ sport infinity press release en.pdf

Ahsan, T., \& Zaman, A. U. (2014). Household waste management in high-rise residential building in Dhaka, Bangladesh: Users' perspective. International Journal of Waste Resources, 4(1), 1-7.

Aspin, M. (2012). Review of the plastic shopping bags: (Waste Avoidance) Act 2008, Adelaide. http:/www.zerowaste.sa.gov.au/upload/resource-centre/publications/plastic-bag-phase-out/ PBActReview_maspin_Nov2012_2\%20-\%20final.pdf 
C40 Cities. (2020). Advancing towards zero waste declarations. C40 Cities. https://www.c40.org/ other/zero-waste-declaration

City of Berkley. (2005). UN Urban environmental accords. Retrieved from www.ci.berkeley.ca.us/ Planning_and_Development/Energy_and_Sustainable_Development/UN_Environmental_ Accords.aspx

Connett, P. (2010). Zero waste: Zero waste: A key stepping stone to sustainability. American Environmental Health Studies Project (AEHSP) Studies Project (AEHSP), United Nation. https://sustainabledevelopment.un.org/content/documents/presentation_connet.pdf

Connett, P. (2013). The zero waste solution. Vermont: Chelsea Green Publishing.

Crocker, R. (2013). From access to excess: Consumerism, 'compulsory' consumption and behaviour change. In S. Lehmann \& R. Crocker (Eds.), Motivating change: Sustainable design and behaviour in the built environment. London: Earthscan.

Crocker, R. (2017). Somebody else's problem: Consumerism, sustainability and design. Routledge.

Eriksson, O., Carlsson Reich, M., Frostell, B., Björklund, A., Assefa, G., Sundqvist, J. O., Granath, J., Baky, A., \& Thyselius, L. (2005). Municipal solid waste management from a systems perspective. Journal of Cleaner Production, 13(3), 241-252.

Garfield, L. (2018). The simple way this Japanese town has become nearly zero-waste. 31 January 2018. Retrieved from https://www.independent.co.uk/environment/recycling-zero-waste-towngarbage-plastics-kamikatsu-japan-a8187301.html

Geyer, R., Jambeck, J. R., \& Law, K. L. (2017). Production, use, and fate of all plastics ever made. Science Advances, 3(7), e1700782.

Glavic, P., \& Lukman, R. (2007). Review of sustainability terms and their definitions. Journal of Cleaner Production, 15(18), 1875-1885.

Hoornweg, D., \& Bhada-Tata, P. (2012). What a waste: A global review of solid waste management. Urban Development \& Local Government Unit. Washington, DC: World Bank. Hung, M.-L., Ma, H.-w.

Hoornweg, D., Bhada-Tata, P., \& Kennedy, C. (2014). Peak waste: When is it likely to occur? Journal of Industrial Ecology, 19(1), 117-128.

Johnson, B. (2013). Zero waste home: The ultimate guide to simplify your life by reducing your waste. New York: Simon and Schuster.

Kamikatsu. (2018). Population and number of households. Retrieved from http://www.kamikatsu. $\mathrm{jp} /$

Kaza, S., Yao, L. Bhada-Tata, P., \& Van Woerden, F. (2018). What a waste 2.0: A global snapshot of solid waste management to 2050. the World Bank urban development series. https:// openknowledge.worldbank.org/handle/10986/2174

MacBride, S. (2013). San Francisco's famous 80\% waste diversion rate: Anatomy of an Exemplar, Discard Studies. https://discardstudies.com/2013/12/06/san-franciscos-famous-80-waste-diver sion-rate-anatomy-of-an-exemplar/

McCarthy, J. (2018). Adidas is making even more clothes from recycled ocean plastic. Retrieved from www.globalcitizen.org/en/content/adidas-clothes-from-recycled-ocean-plastic/

McCurry, J. (2008). Climate change: How quest for zero waste community means sorting the rubbish 34 ways. The Guardian, published on 5 August 2008. https://www.theguardian.com/ environment/2008/aug/05/recycling.japan

Minderoo Foundation. (2019). Global industry initiative launched to end plastic pollution, media release. Minderoo Foundation. https://www.minderoo.com.au/minderoo-foundation/news/ global-industry-initiative-launched-to-end-plastic-pollution/

Mlynek, A. (2018). How we became a zero waste family. www.todaysparent.com/family/activities/ how-we-became-a-zero-waste-family/

Moss, S. (2019). The zero-waste revolution: How a new wave of shops could end excess packaging. The Guardian, published on 21 April 2019. https://www.theguardian.com/environment/2019/ apr/21/the-zero-waste-revolution-how-a-new-wave-of-shops-could-end-excess-packaging

Palmer, P. (2004). Getting to zero waste. Portland: Purple Sky Press. 
Parley. (2018). The Parley Air Strategy. Retrieved from https://www.parley.tv/oceanplastic/\#themission

Pepper, F. (2017). Australia's obsession with new clothes and 'fast fashion' textiles hurting the environment. $A B C$ Radio Melbourne. https:/www.abc.net.au/news/2017-01-12/australiasobsession-with-new-clothes-hurting-the-environment/8177624

Perry, S. (1978). San Francisco scavengers: Dirty work and pride of ownership. Berkeley: University of California Press.

Princen, T., Maniates, M., \& Conca, K. (2002). Confronting consumption. Cambridge: MIT Press.

Sakano, A. (2017). Zero waste - A way to enrich your life \& the society. TEDx Talks. Retrieved from https://www.youtube.com/watch? $\mathrm{v}=$ pgRnAsK18es

SF Environment. (2019). Focus 2030: A pathway to net zero emissions, SF Environment, California. https://sfenvironment.org/sites/default/files/fliers/files/sfe_focus_2030_report_ july2019.pdf

Slade, G. (2006). Made to break: Technology and obsolecence in America. London: Harvard University Press.

Smart, B. (2010). Consumer society: Critical issues and environmental consequences. London: Sage.

SMH. (2011). Global resource consumption to triple by 2050: UN, The Sydney Morning Herald, 13 May 2011. https://www.smh.com.au/world/global-resource-consumption-to-triple-by-2050un-20110513-1el3q.html

Snow, W., \& Dickinson, J. (2003). The road to zero waste: Strategies for sustainable communities. Auckland: ZeroWaste.co.nz.

Stearns, P. N. (2006). Consumerism in world history: The global transformation of desire. Routledge.

Sturmer, J. (2018). Kamikatsu: The Japanese town working towards a zero-waste goal by 2020 , ABC News, published on 20 May 2018. https://www.abc.net.au/news/2018-05-20/kamikatsuthe-japanese-town-with-45-different-recycling-bins/9776560

Tennant-Wood, R. (2003). Going for zero: A comparative critical analysis of zero waste events in southern New South Wales. Australasian Journal of Environmental Management, 10(1), 46-55.

UN-DESA. (2014). United Nations, Department of Economic and Social Affairs, Population Division (2014). World urbanization prospects: The 2014 Revision, Highlights (ST/ESA/SER. $\mathrm{A} / 352$ ).

UN-HABITAT. (2010). Solid waste management in the world's cities: Water and sanitation in the world's cities (Earthscan Ed.). London: Earthscan.

US-EPA. (1993). In-depth studies of recycling and composting programs: Designs, costs, results. Retrieved from US-EPA, Washington, DC: https://nepis.epa.gov/Exe/ZyPDF.cgi/40001087. PDF?Dockey $=40001087$. PDF

White, M. (2009). The Rise of Consumerism, British Library, London, UK, published on 14 Oct 2009. Retrieved from https://www.bl.uk/georgian-britain/articles/the-rise-of-consumerism

WMC. (2018). Adidas wants to make all products from recycled plastic by 2024. Retrieved from https://wellmadeclothes.com.au/articles/AdidasWantsToMakeAllProductsFromRecycledPlas ticBy2024/

World Bank. (2012). What a waste: A global review of solid waste management. World Bank urban development series. https://siteresources.worldbank.org/INTURBANDEVELOPMENT/ Resources/336387-1334852610766/What_a_Waste2012_Final.pdf

Wynne, E. (2017). War on waste: How a capsule wardrobe could help you break your mindless shopping habit, ABC Radio Perth. https:/www.abc.net.au/news/2017-05-31/war-on-wastecapsule-wardrobe-lessen-fashion-spend/8573336

Xing, K., Qian, W., \& Zaman, A. U. (2016). Development of a cloud-based platform for footprint assessment in green supply chain management. Journal of Cleaner Production, 139, 191-203.

Zaman, A. U. (2016). A comprehensive study of the environmental and economic benefits of resource recovery from global waste management systems. Journal of Cleaner Production, 124(2016), 41-50. 
Zaman, A. (2017). A strategic framework for working toward zero waste societies based on perceptions surveys. Recycling, 2(1), 1.

Zaman, A., \& Ahsan, T. (2019). Zero-waste: Reconsidering waste management for the future. London: Routledge.

Zero Waste Home. (2018). Zero Waste Home. Retrieved from https://zerowastehome.com/about/ bea/

Zheng, J., \& Suh, S. (2019). Strategies to reduce the global carbon footprint of plastics. Nature Climate Change, 9(5), 374.

ZWA. (2018). Zero waste Kamikatsu: The zero waste measures of Kamikatsu. Retrieved from http://zwa.jp/wp/wp-content/themes/zwa/assets/pdf/ZeroWaste\%20in\%20Kamikatsu_ infobook_2018.pdf

Open Access This chapter is licensed under the terms of the Creative Commons Attribution 4.0 International License (http://creativecommons.org/licenses/by/4.0/), which permits use, sharing, adaptation, distribution and reproduction in any medium or format, as long as you give appropriate credit to the original author(s) and the source, provide a link to the Creative Commons license and indicate if changes were made.

The images or other third party material in this chapter are included in the chapter's Creative Commons license, unless indicated otherwise in a credit line to the material. If material is not included in the chapter's Creative Commons license and your intended use is not permitted by statutory regulation or exceeds the permitted use, you will need to obtain permission directly from the copyright holder.

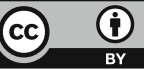

